Check for updates

Coventry and Warwickshire Health and Care Partnership, Rugby, UK

Chrisham01@aol.com

Cite this as: BMJ 2020;371:m3922

http://dx.doi.org/10.1136/bmj.m3922

Published: 14 October 2020

\section{Covid-19 exposes NHS fault lines in England}

\author{
Legislation is needed to ensure collaboration between organisations
}

\section{Chris Ham chair}

Everything in the NHS changed in March when national and local leaders acted to prepare for the rapid increase in demand for care foreshadowed by experience in countries affected earlier in the covid-19 pandemic. Hospitals reorganised their services to increase intensive care capacity, discharge patients to free up beds, and redeploy staff to support the treatment of patients with covid-19.

National leaders commissioned additional capacity in the Nightingale hospitals to avoid patients being denied care at the peak of the pandemic. General practices collaborated by designating some surgeries for the assessment of patients with covid-19 and others for the treatment of non-covid problems.

All of these actions prevented the NHS from being overwhelmed by the pressures created by covid-19 in the first wave, but the experience also served as a salutary reminder of longstanding and persistent challenges in health and care in England. Three stand out.

Firstly, covid-19 affected some communities more than others, most clearly in the adverse effect on people living in areas of social and economic deprivation and those from ethnic minority backgrounds. ${ }^{1}$ The resulting inequalities highlighted how the wider determinants of health and wellbeing-accentuated by a decade of austerity-continue to shape health outcomes. In so doing, they reinforced research on the persistence of the health divide in England. ${ }^{2}$

Secondly, covid-19 underlined the neglect of social care. The sector did not receive the same priority as the NHS in the initial response to the pandemic, and over 15 ooo care home residents died as a result. ${ }^{3}$ The challenges facing social care have a long history and reflect the failure of politicians of all parties to agree how care should be sustainably funded. A succession of reviews proposed reform, ${ }^{45}$ but these have not been acted on and the current government has yet to publish its plans despite high profile promises to "fix social care once and for all." 6

\section{Unfit for purpose}

Thirdly, covid-19 showed that the organisation of the NHS in England is not fit for purpose. The separation of commissioner and provider roles, the

fragmentation of provision between NHS trusts, and the legacy of over 30 years of market oriented reforms made it difficult to plan for the needs of whole populations, despite examples of closer collaboration in some areas. The establishment of sustainability and transformation partnerships, known as integrated care systems in their more advanced form, is a conscious attempt to tackle this challenge, but these partnerships and systems have no basis in law and are still evolving. ${ }^{7}$

The need to improve how care is delivered is arguably even greater now as the NHS prepares for the winter and begins to restore services for non-covid patients. Over the summer, sustainability and transformation partnerships and integrated care systems developed plans for delivering these objectives. These plans include dividing hospitals into those treating covid-19 and those treating other conditions that should remain covid free, separating urgent and elective work where this will bring benefits, and providing care in different settings-proposals to do diagnostic tests for patients with suspected cancer in repurposed high street buildings, for example.

Making a reality of these plans will involve difficult decisions about how and where some services should be provided to improve outcomes. NHS organisations will need to collaborate closely with their neighbours and to take a population perspective instead of acting independently. Sustainability and transformation partnerships and integrated care systems have no powers to force collaboration, and their effectiveness hinges on the willingness of partner organisations to find common cause, which isn't always forthcoming.

The risk then is that NHS organisations may be unable to reach agreement, and some may even veto changes that could benefit patients. To avoid this risk, the government should introduce legislation to give integrated care systems the powers to implement their plans and to enable worthwhile innovations to be sustained and extended. Failure to legislate will mean opportunities to improve patient care are lost at the very time they are most needed.

The government must play its part by coming forward with credible proposals for reforming social care and tackling health inequalities. These longstanding and persistent challenges can only be dealt with through a commitment to action across government backed up by resources in the forthcoming spending review. There could be no better way of fulfilling the prime minister's often expressed ambition to "level up" life chances and prosperity across England, ${ }^{8}$ an ambition that requires government intervention on a scale last seen in the post-war period, when the foundations of the welfare state were laid.

Competing interests: I have read and understood BMJ policy on declaration of interests and declare that I receive remuneration from the NHS as chair of the Coventry and Warwickshire Health and Care Partnership, co-chair of the NHS Assembly, and non-executive director of the Royal Free London Hospitals NHS Foundation Trust. I am the former chief executive of the King's Fund.

Provenance and peer review: Not commissioned; not externally peer reviewed. 
1 Office for National Statistics. Coronavirus (covid-19) related deaths by ethnic group, England and Wales: 2 March 2020 to 10 April 2020. https://www.ons.gov.uk/peoplepopulationandcommunity/birthsdeathsandmarriages/deaths/articles/coronavirusrelateddeathsbyethnicgroupenglandandwales/2march2020to10april2020

2 Marmot M. Fair society, healthy lives. 2010 http://www.instituteofhealthequity.org/resourcesreports/fair-society-healthy-lives-the-marmot-review/fair-society-healthy-lives-full-report-pdf.pdf

3 Office for National Statistics. Deaths registered weekly in England and Wales, provisional: week ending 25 September 2020. https://www.ons.gov.uk/peoplepopulationandcommunity/birthsdeathsandmarriages/deaths/bulletins/deathsregisteredweeklyinenglandandwalesprovisional/weekending25september2020https://twitter.com/ONS/status/1313399088596082689?s=20

4 Dilnot A. Fairer care funding. $2011 \mathrm{https}: / /$ webarchive.nation-

alarchives.gov.uk/20130221121529/https://www.wp.dh.gov.uk/carecommission/files/2011/07/Fairer-Care-Funding-Report.pdf

5 Barker K. A new settlement for health and social care: final report. 2014. https://www.kingsfund.org.uk/publications/new-settlement-health-and-social-care

6 Cambell D. Pledges to fix social care could cost Boris Johnson dearly. Guardian 2019 Aug 1. https://www.theguardian.com/uk-news/2019/aug/01/promising-to-fix-social-care-could-costboris-johnson-dearly

7 Charles A, Wenzel L, Kershaw M, Ham C, Walsh N. A year of integrated care systems. 2018. https://www.kingsfund.org.uk/publications/year-integrated-care-systems

8 Prime Minister's Office. The Queen's speech 2019. https://assets.publishing.service.gov.uk/government/uploads/system/uploads/attachment_data/file/853886/Queen_s_Speech_December_2019_-_background_briefing_notes.pdf

This article is made freely available for use in accordance with BMI's website terms and conditions for the duration of the covid-19 pandemic or until otherwise determined by BMJ. You may use, download and print the article for any lawful, non-commercial purpose (including text and data mining) provided that all copyright notices and trade marks are retained. 